\title{
Development of Human Potential in Countries of the European Union
}

\author{
Natalya Vyacheslavovna Proskurina \\ Olga Vyacheslavovna Bakanach \\ Yury Alekseevich Tokarev
}

\author{
Mikhail Yuryevich Karyshev
}

Department of Statistics, Samara State University of Economics, Samara, Russia; Correspondence: Proskurina Natalya Vyacheslavovna, Department of Statistics, Samara State University of Economics, Samara, Russian Federation

\section{Doi:10.5901/mjss.2015.v6n6s3p351}

\section{Abstract}

\begin{abstract}
Now in today's economy there are high requirements to the quality of human resources in connection with their priority role for economic growth in comparison with material resources. The concept of human capital is often used in economic literature and becomes too narrow. Therefore, consideration of the concept of human potential, expressing a variety of personal abilities of the individual, realization of which brings him not only economic benefits, is important. The aim is the comprehensive statistical analysis of human development in the European Union. The target of this research - countries of the European Union and their social and economic situation in the modern world. The subject of research - quantitative regularities and factors of crosscountry differences of statistical indicators characterizing human development. To implement this target the authors have implemented the following tasks: 1. To implement the group data by the level of human development in countries which belong to the European Union, with the release of groups with different levels of human development in 2012 and 2013, respectively; 2. To rank the EU countries according to values of human development index in 2012 and 2013; 3. To assess changes in the ranking of countries in 2013 compared with 2012.
\end{abstract}

Keywords: human development index, human potential, typology of countries, the European Union, Gender Inequality Index.

\section{Introduction}

\subsection{Representation of the problem}

Human development is a process of expanding people's freedoms to live long, healthy and creative life to achieve the objectives that they have reasons to value; actively participate in ensuring equitable and sustainable development on the planet.

Human Development Index (HDI) - a combined index that is the average of three basic dimensions of human development:

1. Health and longevity, measured indexes by life expectancy at birth;

2. Knowledge, measured indexes by the adult literacy rate and combined gross enrollment ratio;

3. Decent standard of living, indexes measured by the value of the gross domestic product (GDP) per capita in US dollars at purchasing power balance (PPB).

Until 2103 this index was called "Human Development Index" (HDI). Every year since 1990 the UNDP publishes the "Human Development Report", which highlights the problem of human development on a global scale.

The information base of this research: Human Development Report - 2013 of the United Nations, "The Rise of the South: Human Progress in a Diverse World", Human Development Report - 2014 of the United Nations "Sustainable human progress: Reducing vulnerability and formation of resilience", statistical data of Federal State Statistics Service of the Russian Federation.

To compare the areas by the level of social development it is necessary to use generalizing characteristics, reflecting the end result of economic and social policies. Human development index, the most commonly used for this purpose - is a system of indicators adopted for integrative assessment of the quality of people's lives, developed by United Nations Development Programme (UNDP).

The methodology for calculating Human Development Index has repeatedly changed, expanding with each new 
report of its assessment of new indicators and tables. So, consideration of the extended system of indicators is important because it consists of the following indicators: control over resources; health; education; social integration; international flows of trade in goods and services; international capital flows and migration; innovation and technology; environment; population trends.

\subsection{Literature review}

A man and his productive capacity have traditionally occupied a central place in economic and social sciences. But rapid development of material-technical base of production, associated with the industrial revolution, obscured issues of human development and productive capacity that have always been considered by economists as one of the most important quantitative factors of production.

As a result of a long development process, that has studied the man as the subject of the economic life, there could be seen a whole range of categories, "labor", "human resources", "labor potential", "human factor", "human capital".

There has been gradual development of the man's increasing role in the economy and increased attention to its comprehensive study. At the time when this or that concept appears, it bears a clearly defined meaning. But later it is interpreted from the perspective of modern knowledge about a man who becomes a protagonist of the progress. In business philosophy in the West there is a turn to the man, to his knowledge, motivation, and qualification of labor.

The theory of human development based on the theory of production, is formulated by the classics of economic science: W. Petty (Petty, 1690), Adam Smith, David Ricardo (Ricardo, 1817), J.S. Mill (Mill, 1848) developed methodological principles, which then allowed to analyze such intangible elements of production, as knowledge, experience, employee, his skills. For example, Adam Smith and his followers believed that a human was a source and a part of social wealth (Smith, 1776). Marx, examining labor costs, workers' skills, his skill and creative nature of work, made a great contribution to the theory of human development. He presented and studied the definition of the category "variable capital", which in the economic content is closer to the modern concept of "human development" (Marx, 1867). J. B. Clark (Clark, 1886), A. Marshall (Marshall, 1890), I. Fisher (Fisher, 1911) and many other scientists developed theoretical background of the concept of human potential.

Among Russian researchers we should mention I.I. Yanzhul (Yanzhul, 1904), D.I. Mendeleev (Mendeleev, 1907), S.G. Strumilin (Strumilin, 1958) and several others, who emphasized the important role of education in development of production and accumulation of national wealth. And among the Russian scientists there were not only representatives of the economy or sciences related to it, but also natural areas of science. In the second half of the XX century G. Becker (Becker et al., 1962, 1964), M. Blaug (Blaug, 1970), S. Bowls (Bowls, 1970, 1971), J. Mincer (Mincer, 1975), F. Machlup (Machlup, 1984) and others accessed to the theory of human capital. The theory of formation and efficient use of creative and intellectual characteristics of individuals, where the categories of analysis were "labor", "human resources", "human factor", have been developed in national economics by A.I. Barabanov (Barabanov, 1984), S. A. Dyatlov (Dyatlov, 1992), L.E. Melnick (Melnick, 1988), V.T. Pulyaev (Pulyaev, 1987), B.G. Ruzavina (Ruzavina, 1974) and others. T. Schultz, in defining the concept of human capital, based on the following aspect: all human resources and capabilities are either congenital or acquired. Everyone is born with an individual set of genes determining his innate human potential. Acquired valuable human qualities that can be amplified by corresponding attachments, we call human capital (Schultz, 1971).

In economic science at the end of the XX century, there were growing perceptions of human capabilities in reproduction. In this area we should mention V. Gojlo (Gojlo, 1998), S. Klimov (Klimov, 2000), L. Prusak (Prusak, 1997), T. Stewart (Stewart, 1997), L. Edvinsson (Edvinsson et al., 1997) and other researchers. The scientists developed applied aspects in the theory of intellectual potential, such as accounting and valuation of intellectual resources of the company in the form of intangible (intellectual) assets (Sakseltsev, 2005). The concepts of human resources development, knowledge management are trend directions of research to analyze the influence of human capital accumulation on productivity of economic entities' activity.

The genesis of scientific ideas and views on human potential is characterized by a diversity of approaches. At the same time we note that there is a lack of the holistic concept in human development. Some theoretical aspects of human development have remained insufficiently studied, such as the nature, structure, specific economic relations in transformation of the educational environment, especially its reproduction.

In modern literature approaches which consider the totality of human's qualities properties as a resource, are estimated negatively. B. G. Yudin said that the desire to take into account human qualities was due to attempts to improve economic and organizational systems, improve their manageability, and so on. The quest for integral representation of human development has led to formation of the concept of human development, considering it together with social qualities (the standard of living) and biological conditions of existence (health) and social opportunities 
(education). Development of these qualities is possible only if there is a particular combination of features in human development (Yudin, 1998). The value of elements in human development is determined by the action subject which uses this potential.

Modern understanding of social development is based on recognition that the man is the source, and the starting and end-point in social and economic development. Human or social measurement of development is decisive and tangible potential - is the condition for this development.

\subsection{Hypotheses and Their Correspondence to Research}

Improving the methodology for calculating $\mathrm{HDI}$, using new indicators and the new functional form, has led to significant changes. The geometric mean produces lower index values, when the largest changes take place in countries with uneven development measurements. The geometric mean has little effect on the rating of HDI. Establishing the upper bounds at actual maximum values has less impact on overall index values and has less influence on ratings.

In addition to addressing human development index there is an index of human development, taking into account inequalities (IHDI), which expresses the actual level of human development (including inequality), while human development index characterizes the level of human potential development, which can be achieved if the country's achievements are evenly distributed among its inhabitants.

Also in the UNDP report there is presented experimental composite index of inequality among men and women's achievements - Gender Inequality Index, which reflects three dimensions: reproductive health, empowerment, labor market. The high value of Gender Inequality Index is characterized by significant inequality between men and women.

A key focus of social and economic development is to improve conditions and opportunities for livelihoods, enhancing human capital as the basis for economic growth in the long term. In assessing social and economic development of the country, regional comparisons play an important role. The authors agree with V. P. Kandilov's opinion that when there is such comparison it is essential to take into account the specificity of the subject of available resources: natural, economic, human, informational, and others. (Kandilov, 2007). With all conventions this comparison reveals the main trends in the economy, which are certainly important for municipalities, as they allow assessing dynamics, structural characteristics, and features used by the complex of social and economic indicators.

\section{Method}

In this research work, the authors used scientific methods of knowledge - analysis, synthesis, generalization, description; method of empirical knowledge - comparison; methods of system analysis, time series analysis, cluster and regression analysis.

This research is based on official statistics: reports of UNDP, statistical compilations of the Federal State Statistics Service. The paper also used computer technology, in particular application packets of Statistica 10.0 and IBM SPSS Statistics 21.0.

This work considered the following system of indicators related calculation of $\mathrm{HDI}$ :

1. Control over resources:

- Gross national income per capita, USD at purchasing power balance;

- Gross Domestic Product per capita, USD;

- Gross fixed capital formation, \% of the gross domestic product;

- Central government's total expenditure on final consumption, health care, education,\% of the gross domestic product.

2. Health:

- Life expectancy at birth, years;

- Vaccination coverage, $\%$ of children aged 1 ;

- Prevalence of human immunodeficiency virus among young people, \% of the age group 15-24 years old;

- Mortality rate per 1000 people;

- The amount of doctors per 1000 people;

- Satisfaction with the quality of care, $\%$ of respondents expressing satisfaction.

3. Education:

- The average duration of training, years;

- The expected duration of training, years; 
- Proportion of the population with at least secondary education, $\%$ of people aged 25 and older;

- Gross enrollment ratio of education,\%;

- Satisfaction with the quality of education,\% of satisfied people;

- Leaving rate of primary school, \% of students at primary school.

4. Social integration:

- The share of employment in the total population, $\%$ of people aged 25 and older;

- Youth unemployment,\% of people aged 15-24;

- Child labor,\% of children aged 5-14;

- Overall satisfaction with life (10-point scale);

- Perception of safety, \% of people who answered "yes";

- The amount of murders per 100000 people.

5. International trade flows in goods and services:

- Exports of goods and services, billion USD and \% of the gross domestic product;

- Imports of goods and services billion USD and \% of the gross domestic product;

- The share of exports of goods, $\%$

- The share of imports of goods, \%.

6. International capital flows and migration:

- Foreign direct investment, net inflows, \% of the gross domestic product;

- Private capital flows, $\%$ of the gross domestic product;

- Net migration rate, per 1,000 people;

- International inbound tourism, thousand people.

7. Innovation and Technology:

- Expenditure on research and development, \% of the gross domestic product;

- The amount of scientific workers per 1000000 people;

- University graduates in natural sciences and engineering, $\%$ of the total population;

- Electrification rate,\% of the population and others.

8. Environment:

- Emissions of carbon dioxide per capita in tones;

- Depletion of natural resources, \% of the gross national income;

- Freshwater consumption, $\%$ of total renewable water resources.

9. Trends in population:

- The total demographic dependency ratio per 100 people aged 15-64;

- The total fertility rate, births per 1 woman;

- The amount of urban population, $\%$.

Analysis of reliability indicates that $\mathrm{HDI}$ for most countries is not statistically significant after the third decimal place, so countries, that have the $\mathrm{HDI}$ value equal to the third decimal place, are assigned the same rating. Human Development Index (HDI), Adjusted Inequality Human Development Index (IHDI), Gender Inequality Index (GII) and Multidimensional Poverty Index (MPI) - four composite human development indexes were firstly presented in the "Human Development Report" in 2010. Moreover, Gender Inequality Index and Multidimensional Poverty Index are experimental indexes.

Countries are ranked in accordance with the values of $\mathrm{HDI}$. The difference between the ratings of the gross national income and the rating of HDI shows the cost-effectiveness of the country that uses its national income to progress on two dimensions of $\mathrm{HDI}$, unrelated to income. Calculation of $\mathrm{HDI}$, which is not linked to income, is made to provide a means of inter-country comparison, and to determine the ranking of countries on measurements unrelated to income.

$\mathrm{HDI}$ is the geometric mean of three indices measuring:

$I_{\text {Life }}{ }^{1 / 3} \cdot I_{\text {Education }}^{1 / 3} \cdot I_{\text {Income }}^{1 / 3}$

Expression provides incomplete interchangeability of all measurement of this index. It takes into account one of the most serious objections to the linear aggregation formula, which allowed interchangeability of dimensions. The smallest interchangeability is inevitably inherent in the definition of any index and it increases with component values. 


\section{Results}

The authors analyzed theoretical and methodological provisions for calculating HDI, performed univariate and multivariate groupings of European Union countries and built their ranking, identified and measured the main factors influencing differences between countries.

Analyzing inter-country differences, we can say that the human potential of the European Union at the beginning of the XXI century grew up and in 2012 it was not less than 0.75 , which corresponds to high and very high levels of human development among countries of the world. Most human development corresponds to countries such as the Netherlands, Germany, Ireland, the least developed - Romania and Bulgaria.

Comparison of human development indices in the context of the European Union will allow getting cross-country comparison of the level of human development, while highlighting the features of these countries.

To analyze the level of human development in the EU the authors conducted the grouping using HDI with three groups: a group with a high level of human development, a group with an average level of human development, a group with a low level of human development, respectively, in 2012 and 2013.

As a result of grouping data on HDI 2012, the authors achieved the following results:

The group with a very high level of human development includes such countries as: Austria, Belgium, Denmark, Germany, Ireland, Italy, the Netherlands, Slovenia, Finland, France, Sweden.

The group with a high level of human development includes such countries as: Great Britain, Hungary, Greece, Cyprus, Luxembourg, Malta, Slovakia, the Czech Republic, Estonia.

The group with an average level of human development includes such countries as: Bulgaria, Latvia, Lithuania, Poland, Portugal, Romania, Croatia.

The value of $\mathrm{HDI}$ for groups with different levels of human development was the following:

- For a group with a very high level: from 0.875 to 0.921 ;

- For a group with a high level: from 0.828 to 0.875 ;

- For a group with an average level: from 0.782 to 0.828 .

As a result of grouping data on HDI 2013, the authors achieved the following results:

The group with a very high level of human development includes such countries as: Austria, Belgium, Britain,

Denmark, Germany, Ireland, Italy, Luxembourg, the Netherlands, Slovenia, Finland, Sweden.

The group with a high level of human development includes such countries as: Greece, Spain, Cyprus, Lithuania, Malta, Poland, Slovakia, the Czech Republic, Estonia.

The group with an average level of human development includes such countries as: Bulgaria, Hungary, Latvia, Portugal, Romania, Croatia.

The value of $\mathrm{HDI}$ for groups with different levels of human development was the following:

- For a group with a very high level: from 0.869 to 0.915 ;

- For a group with a high level: from 0.822 to 0.869 ;

- For a group with an average level: from 0.777 to 0.823 .

The value of HDI for the European Union as a whole amounted to 0.862 in 2012 and 0.856 in 2013, indicating a decrease in the level of human development in 2013 compared with 2012. This change can be explained by the fact that in most countries the value of HDI declined. Increasing of HDI was observed only in six countries: the United Kingdom, Lithuania, Luxembourg, Poland, Portugal, Croatia.

However, it should also be noted that in 2013 compared with 2012, the number of countries with a very high level of human development increased by 1 country, while the group of countries with an average level of human development decreased by one country, which generally is a positive thing.

So, in 2012 the amount of countries with an average level of human development was $25 \%$ of the total number of countries outside the EU, with a very high level - 43\%. In $2013-21 \%$ and 47\%, respectively. The amount of EU countries with a high level of human development in 2012-2013 remained unchanged at $32 \%$.

In order to identify more and less developed countries at the level of human development, there was the rating of the entire population.

While ranking, each country according to its HDI value was given a certain place: 1st place - the country with the highest $\mathrm{HDI}$, the last 28th place - the country with the lowest HDI. The results are given in Table 1. Note: The signs and $\nearrow \searrow$ show increase and decrease the country's position in HDI ranking. In brackets - positive or negative values reflect the number of positions to raise or lower the rating of the country in 2013 compared with 2012. Cells with the value "0" show that the rating of the country remained unchanged. 
Table 1: Ranking of the European Union by HDI (2012 and 2013).

\begin{tabular}{|l|c|c|l|c|c|c|}
\hline \multicolumn{2}{|c|}{2012} & \multicolumn{5}{c|}{2013} \\
\hline Country & HDI & Rating & Country & HDI & Rating & Changes in Rating \\
\hline The Netherlands & 0,921 & 1 & The Netherlands & 0,915 & 1 & 0 \\
\hline Germany & 0,920 & 2 & Germany & 0,911 & 2 & 0 \\
\hline Ireland & 0,916 & 3 & Denmark & 0,900 & 3 & $5>3(+2)$ \\
\hline Sweden & 0,916 & 3 & Ireland Иpлaндия & 0,899 & 4 & $3 \searrow 4(-1)$ \\
\hline Denmark & 0,901 & 5 & Sweden & 0,898 & 5 & $3 \searrow 5(-2)$ \\
\hline Belgium & 0,897 & 6 & The UK & 0,892 & 6 & $13 \nearrow 6(+7)$ \\
\hline Austria & 0,895 & 7 & France & 0,884 & 7 & $10>7(+3)$ \\
\hline France & 0,893 & 8 & Austria & 0,881 & 8 & $7 \searrow 8(-1)$ \\
\hline Slovenia & 0,892 & 9 & Belgium & 0,881 & 8 & $6 \searrow 8(-2)$ \\
\hline Finland & 0,892 & 9 & Luxembourg & 0,881 & 8 & $13>8(+5)$ \\
\hline Spain & 0,885 & 11 & Finland & 0,879 & 11 & $9 \searrow 11(-2)$ \\
\hline Italy & 0,881 & 12 & Slovenia & 0,874 & 12 & $9 \searrow 12(-3)$ \\
\hline The UK & 0,875 & 13 & Italy & 0,872 & 13 & $11 \searrow 14(-3)$ \\
\hline Luxembourg & 0,875 & 13 & Spain & 0,869 & 14 & $13 \searrow 14(-1)$ \\
\hline The Czech Republic & 0,873 & 15 & The Czech Republic & 0,861 & 15 & 0 \\
\hline Greece & 0,860 & 16 & Greece & 0,853 & 16 & 0 \\
\hline Cyprus & 0,848 & 17 & Cyprus & 0,845 & 17 & 0 \\
\hline Malta & 0,847 & 18 & Estonia & 0,840 & 18 & $19 \nearrow 18(+1)$ \\
\hline Estonia & 0,846 & 19 & Lithuania & 0,834 & 19 & $23>19(+4)$ \\
\hline Slovakia & 0,840 & 20 & Poland & 0,834 & 19 & $22 \nearrow 19(+3)$ \\
\hline Hungary & 0,831 & 21 & Slovakia & 0,830 & 21 & $20 \searrow 21(-1)$ \\
\hline Poland & 0,821 & 22 & Malta & 0,829 & 22 & $18 \searrow 22(-4)$ \\
\hline Lithuania & 0,818 & 23 & Portugal & 0,822 & 23 & $24>23(+1)$ \\
\hline Portugal & 0,816 & 24 & Hungary & 0,818 & 24 & $23 \searrow 24(-1)$ \\
\hline Latvia & 0,814 & 25 & Croatia & 0,812 & 25 & $26>25(+1)$ \\
\hline Croatia & 0,805 & 26 & Latvia & 0,810 & 26 & $25 \searrow 26(+1)$ \\
\hline Latvia & 0,786 & 27 & Latvia & 0,785 & 27 & 0 \\
\hline Bulgaria & 0,782 & 28 & Bulgaria & 0,777 & 28 & 0 \\
\hline & & & & & \\
\hline
\end{tabular}

On the basis of statistical data it can be concluded that in the ranking of countries on HDI there have been significant changes - in the same place there were only seven countries: the Netherlands, Germany, Czech Republic, Greece, Cyprus, Romania, Bulgaria. Twelve countries lost their positions in the ranking, among them the most significant decrease in the position had: Malta (4 positions), Hungary, Spain and Slovenia (3 positions). Nine countries improved the position of the ranking. The most significant increase was in the UK (7 positions), Luxembourg (5 positions), Lithuania (4 positions).

Thus, the authors concluded that there was a decrease in values of HDI in 2013 compared with 2012. Therefore, the level of human development in the European Union has decreased as a whole. This change can be explained by the fact that the level of HDI fell in most EU countries. $42.9 \%$ lost their positions, 32.1\% in 2013 occupied a higher place in the ranking than in 2012, and $25 \%$ of the countries did not change their positions.

The cluster analysis can provide more objective assessment of differentiation of human development in countries. For its implementation, the authors used the following indicators:

$X_{1}$ - life expectancy at birth, years;

$X_{2}$ - the average duration of training, years;

$X_{3}$ - the expected duration of training, years;

$\mathrm{X}_{4}$ - the gross national income per capita in USD at purchasing power balance.

As a result of the variance analysis there is the hypothesis about inequality of variances between clusters and within them. Thus, a priori set of partitioning into 3 groups is well-founded, so the results can be considered satisfactory. Being based on the amplitude (and significance levels) F-statistics for 2012, the variable "Life expectancy at birth" is primary when deciding on distribution of objects in clusters (Table 2). 
Table 2. Results of the cluster analysis of the European Union (2012)

\begin{tabular}{|c|l|l|}
\hline The cluster number & The composition of the cluster & The features of the cluster \\
\hline 1 & Italy, Luxembourg, the United Kingdom, Greece, Cyprus, Malta, Portugal & A high level of human development in the EU \\
\hline Total in the cluster & \multicolumn{1}{|c|}{7} \\
\hline 2 & $\begin{array}{l}\text { The Netherlands, Germany, Ireland, Sweden, Denmark, Belgium, Austria, } \\
\text { France, Finland, Slovenia, Spain }\end{array}$ & $\begin{array}{l}\text { A very high level of human development in } \\
\text { the EU }\end{array}$ \\
\hline Total in the cluster & \multicolumn{1}{|c|}{11} \\
\hline 3 & $\begin{array}{l}\text { The Czech Republic, Estonia, Slovakia, Hungary, Poland, Lithuania, Latvia, } \\
\text { Croatia, Romania, Bulgaria }\end{array}$ & $\begin{array}{l}\text { An average level of human development in } \\
\text { the EU }\end{array}$ \\
\hline Total in the cluster & \multicolumn{1}{|c|}{10} \\
\hline Total in regions & \multicolumn{1}{|c|}{28} \\
\hline
\end{tabular}

It can be concluded that in territorial differentiation of countries there are the main tendencies, despite different time periods and parameters under consideration. At the same time taking into account regional differentiation is an important component in conducting analytical and forecasting, social and economic research.

Based on characteristics of three clusters, it seems urgent to investigate the influence of factors on human development index by the method of regression analysis.

As potential factor variables were selected the following indicators:

$X_{1}$ - life expectancy at birth, years;

$X_{2}$ - the average duration of training, years;

$X_{3}$ - the expected duration of training, years;

$\mathrm{X}_{4}$ - the gross national income per capita, USD at purchasing power balance;

$X_{5}$ - the coefficient of economic activity, $\%$ of individuals aged 15 and older;

$X_{6}$ - the total expenditure of the central government on final consumption, $\%$ of the gross domestic product;

$X_{7}$ - the amount of doctors per 1000 people .;

$X_{8}$ - mortality of children under 5 years old, the amount of deaths per 1,000 live births;

$X_{9}$ - the proportion of population with at least secondary education, $\%$ of people aged 25 and older;

$\mathrm{X}_{10}$ - the share of employment in the total population,\% of people aged 25 and older;

$X_{11}$ - youth unemployment, $\%$ of people aged $15-24$;

$X_{12}$ - the cost of research and development, $\%$ of the gross domestic product;

$\mathrm{X}_{13}$ - the amount of scientists, to one million people.

The conducted analysis has shown that consideration of 13 indicators is inappropriate. Factors $X_{2}, X_{5}, X_{7}, X_{9}, X_{10}$, $X_{11}$ practically have no effect on productive value (these factors correspond to small values of pair correlation coefficients), and the factor $X_{13}$ is excluded from the analysis because of its multicolleration.

As a result of this selection there are only six factors that have a significant impact on the effective rate: factors $X_{1}$ (life expectancy at birth), $X_{3}$ (the expected duration of training), $X_{4}$ (the gross national income per capita), $X_{6}$ (total expenditure of the central government on final consumption), $X_{8}$ (mortality of children under 5 ), $X$ (spending on research and development). Although there were only two statistically significant factors $-X_{3}$ and $X_{4}$.

To assess selection quality of a linear function the authors calculated the multiple coefficient of determination $\left(R^{2}\right)$, which describes the variance proportion of resultant variable $\mathrm{Y}$, due to changes of factor variables included in the multivariate regression model.

In this case, $R^{2}=0,871$, i. e. the multiple regression equation explains $87.1 \%$ of the variance resultant variable and $12.9 \%$ of the residual variance.

When using a linear model of multiple regression equations the authors achieved the following results: $\hat{Y}=0,521+0,0145 x_{3}+0,000003 x_{4}$

Thus, increasing the expected duration of training by 1 year, $\mathrm{HDI}$ increased by $1.45 \%$ at average. With an increase in the gross national product per capita by $1 \$$ US, the value of $\mathrm{HDI}$ also increases by $0.0003 \%$ at average. Inequality Human Development Index (Table 3) is adjusted in relation to traditional Human Development Index. The difference between these rates, expressed in percentage, means a reduction in the level of potential human development due to inequality. As for the difference between the ratings of $\mathrm{HDI}$ and IHDI, it shows that the country's rating for inequality decreases (if it is negative) - Italy, Cyprus, Greece, Spain, Belgium, France, Lithuania, Latvia or it increases (if it is positive) - Slovenia, Slovakia, Czech Republic, and others (according to 2012). 
Table 3. Adjusted Inequality Human Development Index, Gender Inequality Index in 2012 in the EU

\begin{tabular}{|l|c|c|c|c|c|c|c|}
\hline EU countries & \multicolumn{2}{|c|}{$\mathrm{HDI}$} & \multicolumn{2}{|c|}{ Adjusted Inequality Human Development Index (IHDI) } & \multicolumn{2}{c|}{ Gender Inequality Index (GII) } \\
\hline The Netherlands & 4 & 0,921 & 0,857 & 6,90 & 0 & 1 & 0,045 \\
\hline Germany & 5 & 0,920 & 0,856 & 6,90 & 0 & 6 & 0,075 \\
\hline Ireland & 7 & 0,916 & 0,850 & 7,20 & 0 & 19 & 0,121 \\
\hline Sweden & 7 & 0,916 & 0,859 & 6,20 & 3 & 2 & 0,055 \\
\hline Denmark & 15 & 0,901 & 0,845 & 6,20 & 3 & 3 & 0,057 \\
\hline Belgium & 17 & 0,897 & 0,825 & 8,00 & -1 & 12 & 0,098 \\
\hline Austria & 18 & 0,895 & 0,837 & 6,60 & 3 & 14 & 0,102 \\
\hline France & 20 & 0,893 & 0,812 & 9,00 & -2 & 9 & 0,083 \\
\hline Finland & 21 & 0,892 & 0,839 & 6,00 & 6 & 6 & 0,075 \\
\hline Slovenia & 21 & 0,892 & 0,840 & 5,80 & 7 & 8 & 0,080 \\
\hline Spain & 23 & 0,885 & 0,796 & 10,10 & -1 & 15 & 0,103 \\
\hline Italy & 25 & 0,881 & 0,776 & 11,90 & -4 & 11 & 0,094 \\
\hline Luxembourg & 26 & 0,875 & 0,813 & 7,20 & 4 & 26 & 0,149 \\
\hline The UK & 26 & 0,875 & 0,802 & 8,30 & 2 & 34 & 0,205 \\
\hline The Czech Republic & 28 & 0,873 & 0,826 & 5,40 & 9 & 20 & 0,122 \\
\hline Greece & 29 & 0,860 & 0,760 & 11,50 & -3 & 23 & 0,136 \\
\hline Cyprus & 31 & 0,848 & 0,751 & 11,50 & -4 & 22 & 0,134 \\
\hline Malta & 32 & 0,847 & 0,778 & 8,20 & 3 & 39 & 0,236 \\
\hline Estonia & 33 & 0,846 & 0,770 & 9,00 & 2 & 29 & 0,158 \\
\hline Slovakia & 35 & 0,840 & 0,788 & 6,30 & 6 & 32 & 0,171 \\
\hline Hungary & 37 & 0,831 & 0,769 & 7,40 & 3 & 42 & 0,256 \\
\hline Poland & 39 & 0,821 & 0,740 & 9,90 & 0 & 24 & 0,140 \\
\hline Lithuania & 41 & 0,818 & 0,727 & 11,00 & -1 & 28 & 0,157 \\
\hline Portugal & 43 & 0,816 & 0,729 & 10,80 & 1 & 16 & 0,114 \\
\hline Latvia & 44 & 0,814 & 0,726 & 10,90 & -1 & 36 & 0,216 \\
\hline Romania & 56 & 0,786 & 0,687 & 12,60 & 2 & 55 & 0,327 \\
\hline Bulgaria & 57 & 0,782 & 0,704 & 9,90 & 5 & 38 & 0,219 \\
\hline & & & & & & \\
\hline
\end{tabular}

\section{Discussion}

It can be concluded that an important component of the human development strategy is assessment of its value based on the use of appropriate techniques. The method of integrated assessment of human potential, which is the basis of its development strategy, requires to divide human potential assessment into components followed by decision-makers' comparative judgments, as well as to include the synthesis procedure of multiple judgments, to obtain priority factors and find alternative solutions. The results of integrated assessment and calculation of integral index of human development indicators can be final indicators, focusing attention on reserves of the human factor, and they can help us to correct identified inconsistencies.

Despite the fact that countries of the European Union meet high and very high levels of human development among other countries of the world, the place of the European Union is characterized by new conditions of competition, which are to improve human resources and scientific and technological capabilities that meet the requirements of information society, modernization of production, transformation of knowledge into innovation products. Therefore, EU governments and supra-national governments create legal, economic and organizational conditions for establishment of information systems, conduct scientific and technical, educational and innovation policy.

This research can be extended both in terms of time, which involves comparing countries of the European Union over years (in 2014, 2015 and subsequent years) in space, and this comparison is expected to expand the geography of compared territories. And we can talk not only about some countries, but also individual components within them (for example, the subjects of the Russian Federation). 


\section{Conclusion}

The practical significance of this research is that the materials, which are contained in this work and conclusions, can be used at macro- and meso-levels while developing strategies and programs of social development of territories highlighting the priority areas of human development. In addition, the analysis of human development factors can become the information basis for management decisions in development of social and economic policies.

\section{Acknowledgements}

The authors are grateful to E. V. Zarova - Member of the International Statistical Institute, Professor, for detailed examination of this manuscript and valuable comments.

\section{References}

Bobylev, S. N., Grigoriev, L. M., Zubarevich, N. V., Portansky, A. P., Shishkin, S. V., Kurdin, A. (2013) Human Development Report in the Russian Federation - 2013: "Sustainable Development: Challenges of Rio." M.: RA ILF. 202 p.

Govorova, N. (2008) The modern concept of human development. http://www.ieras.ru/journal/journal3.2000/12.htm.

Human Development Report - 2013. The Rise of the South: Human Progress in a Diverse World (2013). M .: All the World. $204 \mathrm{p}$.

Human Development Report - 2014. Ensuring sustainable human progress: Reducing vulnerability and resilience of formation. http://hdr.undp.org/sites/default/files/hdr14-summary-ru.

Elkin, S. E., Kalinina, N. M., \& Bajanova, L.I. (2012, N 3) Features of human potential development in conditions of the modern education system. Modern problems of science and education. http://www.science-education.ru/103-6450.

Kolesov, V. P. (2008) Human Development: a new dimension of social and economic progress. M.: Human Rights. 636 p.

Sakseltsev, I. G. (2005). Conceptual bases of "human potential" concept. Saratov: Volga Region Academy of Public Service. Stolypin. pp. 153-160.

Frolov, I. T. (1999) Human potential: experience of the integrated approach. M.: Editorial URSS. 176 p.

Shamarova, G. (2008, N 8) Problems of human potential management. Personnel Management. http://www.top-personal.ru/issue.html? 1559.

Becker, G. (1993) Human Capital: Theoretical and Empirical Analysis, with Special Reference to Education. University of Chicago Press. $390 \mathrm{p}$.

Schultz, T. (1971). Investment in Human Capital: the Role of Education and of Research. H.Y. 129 p. 